\title{
Organizational Failure: A critique of recent research and a proposed integrative framework
}

\author{
Address for correspondence: \\ Dr. Kamel Mellahi \\ Loughborough University Business School \\ Ashby Road \\ Loughborough \\ Leicester \\ LE11 3TU
}

Tel: 01509223115

Fax: 01509223960

Email: k.Mellahi@lboro.ac.uk

and

Professor Adrian Wilkinson

Loughborough University Business School

Ashby Road

Loughborough

Leicester

LE11 3TU

Tel: 01509228273

Fax: 01509223960

Email: a.j.Wilkinson@lboro.ac.uk 


\title{
Organizational Failure: A critique of recent research and a proposed Integrative Framework
}

\begin{abstract}
There is a long-running debate in the business literature on the causes of organizational failure. On the one hand, classical industrial organization (IO) and organization ecology (OE) scholars have typically assumed a deterministic role of the environment and argued that managers are constrained by exogenous industrial and environmental constraints leaving them with little real strategic choice, and hence managers' role should be ignored. On the other hand, the organization studies (OS) and organizational psychology (OP) literature takes a more voluntaristic perspective and argues that managers are the principal decisions makers of the firm, and consequently their actions and perceptions are the fundamental cause of organizational failure. This paper addresses the major deficiencies observed in the diverse body of literature covering this field, suggests an integrative framework, and identifies the specific theoretical and methodological challenges ahead for researchers seeking to advance knowledge in the field of organizational failure.
\end{abstract}




\section{Introduction}

Since Whetten's (1980) call for more research on organizational failure, there has been a steady increase in research investigating this area. However, literature on failure remains dispersed in various and wide areas of study ranging from industrial organization (IO), organization ecology (OE), and organization studies (OS) to organizational psychology (OP). So far, theoretical and empirical research on failure has reflected a clear divide along the deterministic - IO/OE, and voluntarist - OS/OP - schools. This divide has been sustained by assumptions that the theoretical and methodological differences across these two schools are insurmountable (Witteloostuijn, 1998). As a result, the two schools of thought have evolved independently with little synergy, resulting in theoretical and practical gaps in researchers' understanding of organizational failure.

There is an obvious need to review the current body of literature. First, while the literature on organizational failure continues to grow, proportionately less time has been devoted by scholars to reviewing or capturing the ever-increasing body of knowledge on this topic. Second, we believe that the continued accumulation of fragmented and contradictory findings adds little to researchers' understanding of organizational failure. Third, the review highlights a potential direction for future research efforts.

In this endeavour, we first define the domain of organizational failure. We then organize and review the extensive literature on organizational failure across the two broad IO/OE and OS/OP- theoretical perspectives. The review identifies key theoretical linkages, empirical conclusions, and overall strengths and weaknesses of each perspective. We then propose a framework that represents a start toward building an integrative framework of organizational failure. Finally, we discuss the theoretical contributions of the integrative framework and offer an agenda for future research.

\section{Defining the Domain: What is organizational failure?}

There is no clear consensus within disciplines as to what organizational failure is, how it occurs, and its consequences (Cameron, Sutton and Whetten, 1988; Weitzel and Johnson, 
1989), let alone agreement between disciplines. Several terms have been used in the literatures: organization mortality, organizational death, organizational exit, bankruptcy, decline, retrenchment, downsizing, and failure. In this review we exclude literature on retrenchment and downsizing because we believe that, although, they could be caused by failure, they should not be conceptualized as failure (see Greenhalgh, Lawrance and Sutton, 1988) as they are also associated with the activities of successful organizations. Indeed, because of the recent legitimization of downsizing as an acceptable strategic management tool, managers are increasingly using it during growth periods (McKinley, Zhao and Rust, 2000). We also believe that although bankruptcy filings provide a public record of a firm's demise (Sheppard, 1994; 1995), they reflect only a small portion of business failures. Thus, the large body of accounting and financial management literature seeking to develop financial and accounting models to predict organizational bankruptcy (c.f. Altman, 1970; Altman, 1984; Aziz, Emanuel, and Lawson, 1988; Dambolena, 1983; Dimitras, Zanakis, and Zopounidis, 1996; Johnson, 1970; Mcgurr and Devaney, 1998; Wilcox, 1971) will not be part of this review.

Despite the lack of a precise definition of failure, there is a broad consensus on the meaning of failure. Cameron, Sutton and Whetten (1988:9) define it "as a deterioration in an organization's adaptation to its microniche and the associated reduction of resources within the organization". The result of this could be total exit from the market or turnaround. We will be using exit, death, mortality and failure interchangeably in this article. Symptoms of organizational failure include shrinking financial resources (Cameron, 1983), negative profitability (Hambrick and D'Aveni, 1988; D'Aveni, 1989), shrinking market (Harrigan, 1982), a loss of legitimacy (Benson, 1975), exit from international markets (Burt et al, 2002, and Jackson et al, 2005) and severe market share erosion (Starbuck, Greve and Hedberg, 1978; Mellahi et al, 2002). This broad definition incorporates a number of assumptions: 1) failure generally has negative consequences even though the final outcomes of failure may be positive, i.e. firms learn from failure (Miner, Kim, and Haunschild, 1999); 2) the definition does not specify the causes of failure. It takes into consideration both organizational as well as environmental factors. 


\section{The Deterministic View: The IO/OE Perspective}

While IO and OE scholars disagree on several issues (see Geroski, 2001 ${ }^{\mathrm{i}}$; Barron, 2001; Boon and Witteloostuijn, 1995), they coalesce around the idea that when it comes to failure, the industry matters more than the firm. They agree that organizations are embedded in their environments and therefore, external factors have more explanatory power than firm level factors (see McGahan and Porter, 1997; Rumelt, 1991). That is, failure is caused by external factors over which management has little or no control.

\section{The Industrial Organization Perspective}

Grounded in economics, the IO perspective is underpinned by the Schumpeterian thesis of "creative destruction". According to Schumpeter (1942), jolts in the external environment generate waves of organizational failure. These jolts could be caused by changes of a technological, regulatory, economic or demographic nature (Scott, 1992). For instance, shifts or shakeouts (Nelson, 1995) in the external environment created by revolutionary technological innovation, such as the internet, radically change industrial orders, leading to new entrants to enter the market - such as Amazon.com, and leaving incumbents, that are unable to adapt to the new business environment, to exit the market. Several studies (c.f. Tushman and Anderson, 1986; Sull, et al. 1997) found that, during fundamental transformations of the environment, new firms initiate competencedestroying discontinuities to overthrow incumbent firms.

The IO perspective reflects three underlying assumptions. First, the external environment is assumed to impose pressures and constraints on firms' strategies that would lead to failure. Second, most firms operating in the same industry, or within a certain segment of an industry are assumed to pursue similar strategies. Third, organizational decision makers are assumed to be rational and committed to acting in the firm's best interest, and therefore, failure could not be caused by them alone.

The IO literature suggests a range of primary causes of organizational failure. These include turbulent demand structure due to brand switching by core customers, changes in consumer tastes, cyclical decline in demand, strategic competition due to rivalry among existing competitors or new entrants (Lippman and Rumlet, 1982; Frank, 
1988; Jovanovic and Lach, 1989; Baum and Singh, 1994; Sheppard, 1995). Slater and Nayver (1994) added technological uncertainty due to product innovations and or process innovations to the list of external causes of failure. Dess and Beard (1984) explain the relationship between organizations and the environment by three factors: dynamism, munificence and complexity. Dynamism refers to "change that is hard to predict and that heightens uncertainty for key organizational members" (Dess and Beard, 1984: 56). Uncertainty is a concept frequently associated with the "inability to predict or foresee" (Anderson and Tushman, 2001:683). Anderson and Tushman (2001: 683) argue that dynamism increases organizational mortality rates for two reasons. First, because firms during uncertain times have difficulty accurately predicting circumstances that might effect their future activities, they are more likely to make wrong investments (Ghemawat, 1991; Gemawat and Nalebuff, 1985), sacrifice long term survival strategies for shortterm tactics (Smart and Vertinsky, 1984), and run high risk (Rosenbloom and Christensen, 1994). Second, uncertainty may lead to fluctuations in demand that subsequently cause higher organizational failure (see Anderson and Tushman, 2001: 682689 for a review).

Munificence refers to "the extent that resources available to firms are plentiful or scarce" (Anderson and Tushman, 2001: 689). IO scholars suggest an adverse relationship between failure rates and availability of resources. Further, they proposed a positive correlation between environmental complexity, and organizational mortality rate (Anderson and Tushman, 2001, p.69). Organizational complexity refers to the complex

linkages both within the firm and with external bodies such competitors, stakeholders and institutions (Dess and Beard, 1984).

\section{The Organizational Ecology Perspective}

Organizational ecologists use the dissolution of a firm as the sign of organizational failure. Freeman, Carroll and Hannan (1983: 694) describe dissolution as the state at which an organization "ceases to carry out the routine actions that sustain its structure, maintain flows of resources, and retain the allegiance of its members". 
Over the past 25 years, organizational ecologist scholars have developed a set of statistical tools for examining firm failure (Hannan, and Freeman 1977; Hannan and Freeman, 1989; Hannan and Carroll, 1992). These tools have been used to assess characteristics that may cause the failure or promote the survival of organizational populations (rather than individual firms). The organizational ecology approach has been validated by several studies in a number of industries, including automobile manufacturers (Hannan, 1997; Hannan et al, 1998), breweries (Carroll and Swaminathan, 2000), newspaper publishing (Carroll and Delacroix, 1982), and the hotel industry (Baum and Mezias, 1992).

Although Hannan and Freeman (1977) defined their field of study as population ecology, the terms population ecology and organizational ecology quickly became synonymous, and are often used interchangeably (Scott, 1998). OE derives its ideas from organization theories of the 1950s called human ecology (Hawley, 1950). The underlying theoretical foundation of this approach is the natural selection model (Hannan and Freeman, 1978). The model attempts to explain long-term social evolution, especially the rise and fall of organizational populations. A population comprises organizations sharing a common form or strategy that makes them respond in similar ways to environmental forces (Hawley, 1950). A key emphasis of OE scholars is that other organizations play a role in affecting the chances of success or failure for an organization. Baum and Singh (1994: 5) state that the main purpose of organizational ecology is "to understand the mutual interactions within and among the populations and communities comprising organizational ecosystems and the mechanisms and processes underlying their growth, regulation and decline".

According to OE scholars, four factors determine the chances of success or failure for organizations: population density (Hannan, Barron and Caroll, 1991; Peterson and Koput, 1991; Delacroix, Swaminathan and Solt, 1989; Hannan and Freeman, 1988), industry life cycle (ILC) (Balderston, 1972; Agarwal, Sarkar and Echambadi, 2002), organization age (Baron, West and Hannan, 1994; Bruderl and Schussler, 1990; Fishman and Levinthal, 1991; Levinthal, 1991; Stinchcombe, 1965), and organization size (Barnett and Amburgey, 1990; Hambrick and D’Aveni 1988; Wholey, Christainson and Sanchez, 1992) and we examine these in turn. 


\section{Population Density}

The ecologist approach is built on the "density dependence" logic (Hannan and Freeman, 1989). According to this view organizations' mortality rates depend on the total number of organizations within the relevant population. Crowding intensifies competition, which, in turn, elevates mortality hazards (Dobrev, Kim and Hannan, 2001: 1299). Population density is said to have two separate effects: through legitimation and through competition. The density dependency logic uses density - the number of organizations in a given population at a given time - to explain organizational failure (Hannan, 1986; Hannan and Carroll, 1992; Hannan and Freeman, 1988; Hannan and Freeman, 1989). The key argument here is that the increase in density enhances the institutional legitimacy of a population and consequently the ability of the population's members to attract resources. Prior to acquiring and enhancing legitimation, the number of firms in the population is small, and the enticement to enter the population is low. Legitimation refers to the process by which a certain way of doing things comes to be seen as natural or taken for granted. Because legitimation gives access to resources, it increases founding rates while reducing failure rates. Further, because resources are limited, the increase of new entrants leads to a relative scarcity of resources which lead to high competition between the members of the population and cannibalization amongst the members of the population. That is, rising population density increases both legitimation and competition. Competition, which results from the growing presence of multiple organizations, has a negative impact on the survival rate of incumbents, thus decreasing the density of the population (Hannan and Freeman, 1989). By combining the two opposing effects, legitimation and competition, Hannan and Freeman (1988) suggest a U-shaped relationship between density and failure. They predict that organizational mortality starts high and falls as legitimacy increases, then rises as competition increases.

According to OE scholars, density of the population at the time of founding influences the risk of failure. Because high density at founding "creates a liability of resource scarcity" which could prevent newly founded organizations from "full scale operations and tight niche-packing" (Agarwal, Sarkar, and Echambadi, 2002: 974). This could force newly founded firms to use resources that are inferior to those of established 
organizations" and subsequently, experience higher failure rates" (Agarwal, Sarkar, and Echambadi, 2002: 974). Or simply put, a high number of organizations already occupying a particular niche will make the founding of a new organization in that niche less likely to occur or, if it is founded, to succeed. In addition to the impact of the time of founding, Dobrev, Kim and Hannan (2001: 1300) found that the strategic location of the firm in the niche market has a significant impact on the likelihood of failure. They found that crowding increases the mortality hazards of organizations located in the centre more than the periphery. They argued that this is because when density increases, specialists located in the center have nowhere to hide, whereas "generalists whose niches span the center can potentially offset some of the deleterious effects of crowding in the center" and move to "less competitive regions covered by their wide niches".

\section{Industry Life Cycle Theory}

According to the Industry Life Cycle (ILC) theory, firms follow a priori sequence independent of firms' strategies and management (Klepper, 1997). Its underlying rationale is that organizational failure is a natural and objective phenomenon (Balderston, 1972), inherent to the efficient operation of markets. Boulding (1950: 38) notes that organizations follow the path of "inexorable and irreversible movement toward the equilibrium of death. Individuals, family, firm, nation, and civilization all follow the same grim law, and the history of any organism is strikingly reminiscent of the rise and fall of populations on the road to extinction". Whilst not universally accepted, the concept of cyclical trends or tendencies that need to be managed or overcome is an intuitively attractive one. The ILC approach suggests that failure results from demand saturation, supply running out, or a new technology that promises more value.

\section{INSERT FIGURE ONE HERE}

\section{Age and Failure: The Liability of Newness}

Since Stinchcombe (1965) introduced the concept of a liability of newness to describe the high mortality risk facing new ventures relative to their more mature counterparts, several studies have examined the relationship between age and failure of new ventures and 
found that most organizations die young ${ }^{\text {ii }}$ (Bruno and Leidecker, 1988; Duchesneau and Gartner 1990, Gaskill et al. 1993; O'Neill and Duker, 1986, and Swaminathan, 1996; Carroll, 1983; Carroll and Delacroix, 1982). Freeman, Carroll and Hannan's (1983) study of National Labour Unions in newspaper publishing, and semiconductor manufacturing in the US provided evidence to support the inverse relationship of age and firm failure. The liability of newness perspective argues that because it is harder to create new routines and effective management structures than to continue with an already established one, older firms with established routines, and management structure have an advantage over younger ones (Nelson and Winter, 1982). Similarly, Stinchcombe (1965) argues that young organizations, which are often resource-strapped, have less experience, fewer slack resources, and fewer constituencies that could give them support and social capital than older organizations. Thus, according to Stinchcombe (1965), the high rate of failure of new firms arise from the required costs of learning new tasks and processes, the necessity to invest new roles and the conflict such roles presents, the absence or weakness of formal structures, and the lack of stable links with customers. Hannan and Freeman (1989) cite lack of organizational stability to engender customer trust as one of the reasons for high mortality risks of new businesses. Key constraints on young organizations included: raising capital; tax laws; government regulation and competition for labor (Aldrich and Auster,1986). According to Hannan and Freeman (1984, 1989), new firms enter a Darwinian business world, which, if new firms begin wrongly, are most likely to perish despite their attempts to change their course of action and behaviour. Agarwal, Sarkar and Echambardi (2002) link the liability of newness to the ILC concept and argue that the mortality rate of new firms is higher during the maturity stage and lower during the growth stage. This is understandable as the disadvantages associated with newness are likely to be lower at the growth stage because barriers to entry are lower in the growth stage than in the maturity stage.

In addition to the liability of newness, a significant body of research argues that organizations tend to fail at a young age because of the liability of adolescence (Levinthal and Fichman, 1988; Ingram, 1993; Bruderl and Schussler, 1990). Both the newness and adolescence perspectives argue that the early years of a firm's life are the most crucial and hazardous, and failure rates eventually decline with age (Henderson, 1999). 
However, these perspectives differ in relation to whether firms are most likely to fail at founding or several years later (Henderson, 1999). That is, while the liability of newness theory suggests that, all things being equal, failure decreases monotonically with age the liability of adolescence theory argues that "organizations can survive for a time with little risk of failure because they can draw on the initial stock of assets they typically acquire at founding" (Henderson, 1999), such as venture capital and bank loans - this period often termed initial honeymoon period. As a result, firms face their highest mortality rates several years after their births (see Bruderl and Schussler, 1990, Fishman and Levinthal, 1991).

Liability of newness does not only refer to new ventures, but also to organizations after undertaking major change. OE scholars suggest that because of structural inertia, organizations tend not to change, and when they do, they respond slowly to environmental threats and opportunities, and they are more likely to disband than adapt (Hannan and Freeman, 1984). Simply put, change often leads to failure. Amburgey, Kelly, and Barnett (1993) in a study of Finnish newspapers found evidence to suggest that organizational change, such as changes in the content or frequency of the newspaper, increases the risk of failure. They concluded that organizational change re-exposes the organization to the liability of newness by "resetting the clock". Because change significantly disrupts established routines, inter-organizational relationships and organizational legitimacy, it creates new roles and new relationships similar to those of a new organization, which exposes organizations to a higher risk of failure. In sharp contrast to the above, a significant body of evidence suggests that change does not increase failure rates, rather it increases survival chances (c.f. Stoeberl, Parker and Joo, 1998; Kelly and Amburgey, 1991; Delacroix and Swaminathan, 1991). For instance, Haveman's (1992) study of the saving and loan industry in California found that diversification into markets that are closely related to their core business improve firms' life chances and reduce their failure rate. Greve (1999) notes that organizations that are doing poorly benefit more from change than those organizations that are doing better. Organizational change was also found to have a positive impact on performance when organizations change in order to move to an ecological niche with plentiful resources and few competitors (Barnett, Greve, and Park, 1994), fit their internal strategy with 
environmental conditions (Lawrence and Lorsch, 1967; Miller, 1992), lower their dependence on the environment (Pfeffer and Salancik, 1978), or conform with institutional demands (Meyer and Rowan, 1977).

\section{Size and Failure: The Liability of Smallness}

Several scholars (Hannan and Freeman, 1984; Freeman, Carroll and Hannan, 1983;

Sutton, 1997) have reported that the mortality rate declines with increased size. The liability of smallness suggests that size matters, and bigger is better. In short, the liability of smallness theory advocates that expectations of success favour large firms over small ones and, on average, small firms have a higher likelihood of failure. The liability of smallness stems from the idea that small firms do not perform as well as large firms and have higher failure rates due to problems of raising capital, attracting, recruiting and retaining highly skilled workers, higher administrative costs (Aldrich and Auster, 1986), and legitimacy problems with external stakeholders (Baum and Oliver, 1992; Baum, 1996; Baum and Oliver, 1996). Conversely, large firms have less dependability on external resources (Baum and Oliver, 1996), and greater access to market power (Bain, 1956) than small firms. Agarwal, Sarkar and Echambardi (2002: 979) argue that the liability of smallness varies according to the stage of the ILC. They suggest that it is less of a liability during the mature stage of an industry than during the growth stage. During the mature stage all firms regardless of size face higher mortality rates. However, during the growth stage "there is an unequivocal growth imperative, since the basis of competition puts small firms directly against their larger counterparts" (Agarwal, Sarkar and Echambardi: 978-979).

To summarize, OE scholars believe that the industry/population matters more than the firm's strategy. They argue that because environments change faster than organizations, the performance of the firm is determined by the environment within which it operates and not the firm's strategic choice. Population ecologists also believe that organizations are born and die due mainly to environmental factors.

\section{A Critique of IO/OE Perspective}


The main weaknesses of IO/OE scholars is not what they examine but what they ignore. By putting all the emphasis on external factors, it is unfortunate that little attention has been given to dealing with the question of why is it that firms in the same industry facing the same industry-level constraints fail while other succeed (Flamholtz and Aksehirli, 2000; Mellahi et al, 2002).

In addition, several studies have demonstrated that performance is determined by the firm strategy more than the industry (c.f. Brush, Bromiley and Hendrickx, 1999; Mauri and Michaels 1998). Thus, by concentrating solely on external factors to explain organizational failure, we believe the IO/OE perspective is overly deterministic, and that only the crudest and most extreme external effects can be detected by their research methods. That is, internal factors that could offer a more promising explanation of organizational failure are ignored because they are too subtle to be adequately captured and measured by the rather blunt research tools utilized by these researchers. Consequently, the IO/OE literature has problems both theoretically and empirically in explaining failure. In the next section we turn to the internal causes of organizational failure.

\section{The Voluntaristic View: Organizational Failure From the OS/OP Perspective}

The voluntaristic perspective rejects the assumption that managers are powerless and/or rational actors. Instead, it is predicated on the assumption that managers are the principal decisions makers of the firm (Hambrick et al. 1996; Hambrick and Mason, 1984; Szilagyi and Schweiger, 1984), and their perceptions of the external environment have a strong effect on how they (mis)manage the firm (Mone, McKinley, and Barker, 1998). According to this perspective, management actions are influenced by management mental models of the organization and its environment, and constrained by their existing commitments, power and capacity to implement or enforce them (Greenwood and Hinings, 1996: 1048).

The core thrust of the OS/OP literature is that who makes a decision is more important than the external context within which the decision is made. Larson and Clute (1979) conclude that the characteristics shared by failed firms are directly related to 
personal decision-based characteristics of managers. Similarly, Starbuck, Greve and Hedberg (1978) locate the source of failure in the misperceptions of organizational members. Barmash (1973: 299) notes that "corporations are managed by men; and men, never forget, manage organizations to suit themselves. Thus corporate calamities are calamities created by men".

In essence, the OS/OP perspective argues that failure is linked to internal inadequacies in dealing with external threats. These inadequacies can be of a variety of types. Argenti (1976) identifies as causes of failure impulsive decisions that over extended the organizations assets, not responding to change, an executive who is either too powerful or poorly informed, and the taking of unnecessary risks. Macoby (2000) describes how visionary managers can frequently be narcissistic in their behavior and increase the risk of failure when business conditions change. He argues that when faced with a threat, these narcissist leaders isolate themselves from the advice of others, ignore words of caution, interpret criticisms as threat, and frequently become myopic in their views. This behavior and attitudes fosters hubris because of "exaggerated pride, selfconfidence, or arrogance" (Kroll, Toomb and Wright, 2000). As a result, in the face of internal and or external threats, decision makers will "stick to the knitting" and reinforce well learned past routines and procedures (Staw et al., 1981).

OS/OP literature lacks a grand theory explaining organizational failure. However, several competing middle range theories are developed to explain internal causes of failure. As a result, like in other disciplines, the absence of a grand theory results in contradictory results. For instance, as explained below, a number of scholars have argued that management successions have positive consequences on performance. Equally, others have maintained that management successions lead to poor performance, and failure. To illustrate the arguments concerning causes of failure at the organizational and individual level, we focus on five middle range theories. Although the five theories are related, we analyze them separately for reasons of convenience and simplicity.

Groupthink theory. Groupthink is the term given by Janis $(1972 ; 1982)$ to the tendency of decision makers in small groups to make sub-optimal decisions ${ }^{\text {iii }}$. Janis (1982) argues that extreme pressures for unanimity can build a cohesive group that confronts serious 
threat and lacks norms of deliberative decision making (Peterson et al., 1998). Janus (1982: 243) warns that "even individuals who are generally high in self-esteem and low in dependency and submissiveness... are quite capable of being caught up from time to time in the group madness that produces the symptoms of groupthink". He posits that once the groupthink mentality sets in, a host of pathologies become prevalent, including self-censorship of any misgivings managers may have, collective rationalization, illusion of invulnerability, stereotypes of outgroups, poor search for alternatives, ignorance of outside information, overestimation of the group's chances of success, and biased information processing. Consequently, managers miscalculate events and make decisions that could lead to failure (c.f. Manz and Sims, 1982; Peterson et al., 1998)

Upper Echelon Theory. "Upper echelon" theory (Hambrick and Mason,1984) suggests that the characteristics of an organization's key decision-makers influence strategy and subsequent organizational performance. Two factors are particularly salient with respect to failure: the composition of top management teams and managerial succession.

In relation to the former, research shows that two demographic factors affect top management reaction to failure namely; homogeneity of the top management team (Pitcher and Smith, 2001; Bantel and Jackson, 1989; Greening and Johnson, 1996; Boeker, 1997), and tenure (Mone, McKinley, and Barker, 1998). Homogeneity and heterogeneity of top management have been used as proxies to predict management behaviours and attitudes in organizations facing decline (Pitcher and Smith, 2001, Bantel and Jackson, 1989; Greening and Johnson, 1996). Heterogeneous groups appear to be more effective than homogeneous groups, especially in uncertain and turbulent environments (c.f. Eisenhardt, 1989; Wiersema and Bantel, 1992). However, Fink (1986) argues that in a crisis situation quick decisions need to be taken to minimise a rapidly escalating and potentially catastrophic event. He argues that in such a situation, homogeneous groups can take quick decisions more effectively than homogeneous groups. Mellahi and Jackson's (2002) study of Marks and Spencer shows how early turnaround attempts by a long tenured and homogeneous management team were ineffective because managers failed to successfully diagnose the causes of failure. For instance, management tried to increase efficiency through tactical changes such as cost 
cutting, when the firm's weak strategic position was the cause of the failure. The latter could spiral into "error-amplifying decision traps" (Schulman, 1989) where the wrong response to a problem may inadvertently amplify the problem. A significant body of research suggests that when organizations face an external threat such as a crisis, new managers tend to see the cause of failure as internal, and controllable. In contrast, longertenured top managers perceive the causes of organizational crisis differently from new managers and this influences the manner in which they deal with the crisis (c.f. Mone, McKinley and Barker, 1998). In particular, longer-tenured top managers tend to attribute failure to external, uncontrollable, and temporary causes. As a result, they tend to ignore internal causes of failure and subsequently exacerbate the problem. In particular, research suggests that longer tenured top management are likely to be associated with increased rigidity and commitment to standardised practices (Miller 1991; Katz, 1982), a reduction in information processing over time (Kiesler and Sproull, 1982; Staw et al., 1981; Miller and Friesen, 1984), reliance on increasingly narrow and restricted sources of information (Hambrick and Fukutomi 1991), management cohesion (Michel and Hambrick, 1992), and entrenchment (Wiersema and Bantel, 1992). As a result, long tenured managers tend to spend less time analysing the threats and opportunities facing them (Miller, 1993), and become more convinced of the wisdom of the organization's ways of doing things (Wanous, 1980). Consequently, a long-tenured top-management team may cause organizational failure under conditions of fundamental environmental transformation by becoming entrenched and unreceptive to change (Wiersema and Banter, 1992).

The evidence on the potential influence of management successions is mixed (Alen, Panian, Lotz, 1979; Grusky, 1963). On the one hand, studies investigating the effects of managerial succession on organizational failure suggest that managerial successions make organizational failure more likely (Brown, 1982; Heather, 1993). The negative effects of managerial succession are more likely if a succession takes place in small organizations (Haveman, Mukti, 2003; Alexander and Lee, 1996), early in a firm's life (Carroll, 1984; Haverman, 1993; Singh et al., 1986; Amburgey and Hayagreeva, 1996), or occurs during a crisis (Mellahi et al, 2002). This is because small and young organizations lack experience in dealing with successions, especially the first succession. 
On the other hand, a large body of research proposes that managerial successions have a favourable effect on performance, and hence improve organizational survival chances (Ocasio, 1993). For instance, Guest (1962) found that managerial succession reduced conflict without creating chaos and so improved performance. Similarly, Helmich (1974) and Virany, Tushman, and Romanelli (1992) reported that succession increased growth rates and financial returns, respectively, especially when the successors were outsiders.

Curse of Success. The OS literature indicates that successful companies are susceptible to failure for a range of reasons. Miller (1990) notes that "success can breed over confidence and arrogance". Ranft and O'Neill (2001: 126) argue that high-flying firms, in the face of competitive pressures, develop a form of "cautious conservatism and perhaps arrogant disdain". This can be linked to the idea that "success breeds failure" and "failure breeds further failure" (Starbuck, Greve and Hedberg, 1978; Argenti, 1976), in a spiral of decline. As Kelly and Amburgey (1991) point out over time successful routines develops into habits and routines become traditions, with the effect of preserving the firms way of doing things. As a result, organizations that were the most successful in the past become the most vulnerable to failure in the future (Whetten, 1988).

Threat Rigidity Effect Theory. Threat rigidity effect theory (Staw et al. 1981) argues that individuals, groups and organizations tend to behave rigidly in threatening situations, and seek to maintain the existing status quo. Keisler and Sproull (1982, quoted in D'Aveni and MacMillan, 1990: 635), state that "a crisis is expected to divert a manager's attention away from the locus of the crisis because it creates noise that may keep the manager from considering relevant information about elements in the organization's environment that are the source of the crisis". As a result, managers will not change their focus of attention in response to an externally induced crisis (D'Aveni and MacMillan, 1990), rather they will ignore the external crisis and act as if the external crisis does not exist (Holsti, 1978; Starbuck, Greve, and Hedberg, 1978; Whetten, 1980).

OP scholars suggest that the above managerial (mis)behaviours are a result of, at least in part, factors that often exist beneath the level of conscious awareness. Although 
there is little direct theorizing about the relationship between psychological factors and failure, it has been demonstrated that such factors are critical in shaping management actions that cause failure. OP scholars link organizational failure to hidden, repressed motivations, feelings and dynamics. For instance the psychodynamic perspective would explain the above (mis)behaviour of managers by ego defences that tend to push managers toward a regressive retreat from a changing reality. Hodgkinson and Wright's (2003) study of a private sector organization argued that the failure of the authors' intervention to facilitate learning and strategic renewal at the company was primarily due the participants adoption of "a series of defensive avoidance strategies". The latter is referred to as "cognitive inertia". They argue that once cognitive inertia is established, "there is a danger that actors may become overly dependent on their mental models of strategic phenomena, to the extent that they fail to notice changes in the material conditions of their business environments until these changes have become so widespread, or significant in other ways, that their organization's capacity for successful adaptation has been seriously undermined" (p). They posit that, if left unchecked, the long term consequences of cognitive inertia is business failure.

At an organizational level, ego defences could lead to failure through their influence on the information- processing effects (Miller and Ross, 1975), i.e. people are less likely to perceive a relationship between their behaviour and its outcome when they fail $^{\text {iv }}$; the interpretation of information; the use of information; the storage of information, and the internal recall of information (Brown and Starkey, 2000).

Brown and Starkey (2000) listed five psychodynamic factors that could contribute, at least in part, to organizational failure: denial, rationalization, idealization, fantasy, and symbolization. These factors have been discussed in terms of barriers to learning by organizations and individuals, but they are also relevant to organizational failure. Brown and Starkey (2000) note that through denial, individuals seek to disclaim knowledge and responsibility, to reject claims made on them, and to disavow acts and their consequences. Therefore, denial could have a profound implication for failure. Mellahi and Jackson (2002) described how Marks and Spencer's management rejection of customer feedback surveys, by questioning the validity of data, blinded them and led them to deny that a problem existed until the company faced a full-blown crisis. 
Rationalization - an attempt to justify impulses, needs, feelings, behaviors, and motives that one finds unacceptable so that they become both plausible and consciously tolerable (Brown and Starkey, 2000). Idealization - a process by which some object comes to be "overvalued and emotionally aggrandized" and stripped of any negative features (Laughlin, 1970: 123, cited in Brown and Starkey, 2000). In short, idealization processes help explain why managers tend to escalate their commitment to a failing course of action as they undergo the risk of additional negative outcomes in order to justify prior behaviour (Staw, 1976; Brockner, 1992; Goltz, 1992; McCain, 1986; Ross and Staw, 1993). Fantasy - represents an unconscious endeavor to fulfil or gratify difficult or impossible goals and aspirations (Laughlin, 1970). In organizations, fantasies are forms of collective retreat into imagination, which "converts the ambiguities of history into confirmations of belief and a willingness to persist in a course of action" in ways that are "destructive for the individual organization" (March, 1995: 437). Finally, Symbolization: the process "through which an external object becomes the disguised outward representation for another internal and hidden object, idea, person, or complex" (Laughlin, 1970: 414) is where managers use symbols in organizations as means by which they manipulate and control their organizations (Brown and Starkey, 2000).

\section{Critique of the OS/OP Perspective}

While the richness and diversity of analysis is clearly a key strength of the OS/OP approach, it is the reliance on several middle range theories without an overall "grand theory" which is the source of its main weakness. In contrast to the OE theory, which has a well defined aim and methodology, OS/OP scholars, tend to deal with several, often, uncoordinated issues.

If this is to continue, we believe, the field of organizational failure could become chaotic and could result in a "fragmentation trap" . As a consequence, researchers, management teachers and business students would be faced with a multitude of conflicting and unorganized theories and findings. For instance, do managerial successions increase or decrease organizational failure? Although, one might argue that in order to understand the highly complex reality of organizational failure different middle range theories are 
required since most theories only highlights one aspect of the phenomenon ${ }^{\mathrm{vi}}$, a proliferation of middle range theories could lead the field of organizational failure to become, to borrow from Jeffrey Pfeffer (1982), a "weed patch" rather than a "well-tended garden".

Another common criticism of the OS/OP perspective is its over-reliance on internal factors. By so doing, the internal perspective is limited by its inability to account for the context within which firms operate. Finally, another major defect in attempts to study the link between internal factors and failure may lie in the fact that virtually all such studies are limited to one society, the United States.

\section{Plotting a Path Towards Integration}

As discussed earlier, research on organizational failure has focused so far on within a single perspective approach represented by the dotted lines in Figure 2. However, to develop a better understanding of organizational failure, we believe, it is necessary to understand how external factors and organizational factors interact to cause failure. A conceptual framework depicting the influence of and relationship between the various facets of the external and the internal environments appears in Figure 2. A fundamental axiom of the integrative framework is that the different theoretical assumptions and linkages underlying each perspective are not only reconcilable but that together they provide a more comprehensive understanding of organizational failure than any single perspective by itself.

It is worth noting that environmental or organizational factors can have an independent effect on failure (see doted lines in Figure 2). These direct effects, we believe, are valid only in extreme situations, such as major environmental disaster or economic crisis, or extreme cases of management misbehaviour, as in the cases of Enron and World.com, where the moderation power of remaining factors is very small.

Interactions between the internal environment and facets of the environment are represented by R1 and R2 in Figure 2. At the firm level, the framework shows that, typically management actions alone do not yield an organizational failure. To increase the predictability of management actions, the latter should be examined within the 
framework of the dynamics of the industry and the wider context in which a firm operates. The framework proposes that there will be significant differences in the outcomes of the same internal factors across firms in different business environments. According to the proposed framework, factors emphasized by IO/OE scholars, such as density, ILC, firm's size and age, and environment jolts may mediate the effects of internal factors on organizational failure (R1). How, and the extent to which, external factors magnify or suppress the effects of internal factors is an empirical question. Studies, for example, could compare and contrast the impact of internal political crisis, management successions, or maladaptive management behaviour during growth and decline stages, stable and unstable environments, periods of technological stability and discontinuity, etc. It is highly plausible, for example, that the consequences of management successions are not only likely to vary as a function of the nature of the succession i.e. hostile or friendly, internal or external, but they also depend on the external context within which such successions take place, and the ecological characteristic of the population such as density, ILC stage, and size and age of the organization. One would assume that during the growth period, succession battles or management mistakes might not lead to failure, because the environment is favourable and the organizational could recover from the effects of a bad management decision. However, during a decline stage, survival might be fragile, and the impact of internal factors could have detrimental effects on the organization. Equally, favourable external environmental factors may offset the disruptive effects of internal factors that could cause failure. Organization size and age are also expected to influence the outcome of management successions. Larger and older organizations are likely to possess more experience in dealing with successions, which may enable them to undertake successions without suffering negative consequences. This may be particularly true of organizations with established succession policies and procedures. Younger and smaller organizations, in contrast, may not be able to withstand the potential disruption associated with management successions.

Thus, we suggest that future research on organizational failure should address the following questions: First, what organizational features cause failure in the face of changing circumstances, and under what specific circumstances? Second, under which 
environmental circumstances and ecological factors, do organizational factors increase the risk of failure? Taken together, these questions, we hope, provide insight into the challenging task of identifying and explaining the causes of organizational failure.

\section{INSERT FIGURE TWO HERE}

\section{Methodological Issues}

Although the two broad perspectives are defined in terms of theory, rather than method, the perspectives lend themselves to differing sets of research methods. As noted earlier, each school of thought adheres to its own method, level of analysis, and underlying assumptions.

The lack of consensus about research methods for understanding organizational failure has meant the two groups of scholars have developed and mastered habits of inquiry different enough to resist blending. For instance, according to OE scholars, only longitudinal analyses at a population level using sophisticated, and often, standard equations can be applied to explain, measure and predict organizational failure ${ }^{\text {vii }}$ (Ulrich, 1987; Singh and Lumsden, 1990). Methods in IO research are more likely to involve econometrics models or large survey questionnaires. In contrast, OS and OP researchers are traditionally associated with qualitative research methods using a single organization or a small number of organizations to explain the dynamics of organizational failure.

Given the differences between the two approaches to failure, it is not surprising that researchers taking each perspective have questioned the utility of adopting insights from the other tradition. A common tendency is to dismiss insights from the other perspective based on perceived methodological weaknesses. On one side, OS accounts based on ethnographic observation are often discounted on the basis of inconsistency across studies. Another potential drawback of OS/OP studies is the reliability of data gathered from managers on the causes of failure. Research shows that people tend to overestimate their own influence on successes and to overestimate external or situational influences on failures (Wagner and Gooding,1997; Huff and Schwenk ,1990). In addition, the case study method used in OS/OP approach often result in comparability 
and validity problems stemming from idiosyncratic definitions in single or multiple firm(s) case studies. In brief, although the case-study research on organizational failure has clearly informed the current state of knowledge, without the analytical leverage provided by ecological and environmental approaches to large organizational populations, it would not be possible to draw conclusions regarding the broad environmental dynamics that set the context within which managers in individual organizations operate.

On the other side, IO accounts based on survey data are often dismissed because researchers remained at a distance from respondents, potentially insensitive to how respondents were affected by their questions. OS/OP scholars charge that, because several of the issues causing failure tend to be highly sensitive to the organizational and individual context within which they reside, it is improbable that a simple line of causation will explain the causes of organizational failure.

In order to bridge the gap between the IO/OP and OS/OP bodies of literature, both managerial and external frames of reference need to be reflected in researchers' choice of data sources and data collection methodologies. One could use a combined survey questionnaires, archival data and interviews to provide an accurate measures of managerial cognitions and actions and the external context within which they took place. Furthermore, we suggest that sources of perceptual data, for reasons explained above, should not be limited to managers but could include industry experts and academics leaders in the field of organizational failure.

\section{Conclusion}

In this paper, we have reviewed contributions to the organizational failure literature from different perspective. We hope we have made a widely scattered empirical literature much more available and tractable to scholars. This is made possible by clearly identifying the domain of the phenomenon of organizational failure and the major theoretical links contained within it. We have also addressed the key methodological issues contributing to the divide between the two main schools of thought. Further, we have provided researchers with an integrative theoretical framework and specific research 
questions that directly identify a research agenda for the future. We argue that any attempt to explain organizational failure will not be complete unless the interplay between contextual forces and organizational dynamics is taken into account. The framework proposes that there will be significant differences in the outcomes of the same internal factors across firms in different business environments and vice versa. The researchers who take the next steps in understanding organizational failure should now have a better understanding of the ways in which they can advance the knowledge in this field. We hope that these contributions will be reflected in future research, in which theoretical richness and methodological rigor are combined. 


\section{References}

Agarwal, R. Echambadi, R. and Sarkar, M.B. (2002). The Conditioning Effect of Time on Firm Survival: A Life Cycle Approach. Academy of Management Journal, 45(8), 971-994

Aldrich, H. E. and Auster, E.R. (1986). Even dwarfs start small: Liabilities of age and size and their strategic implications. In Staw and Cummings (eds.) Research in Organization Behavior, JAI Press, pp, 165-198.

Alexander, J.A. and Lee, S.Y.D. (1996). The Effects of CEO Succession and Tenure on Failure of Rural Hospitals. Journal of Applied Behavioral Science, 32(1), 70-88.

Allen, M., Panian, S. and Lotz, R. (1979). Managerial succession and organizational performance: A recalcitrant problem revisited. Administrative Science Quarterly, 24, 167-180.

Altman, E. I. (1970). Ratio Analysis and the Prediction of Firm Failure: A Reply. Journal of Finance, 25(5), 1169-1172.

Altman, E. I. (1984). The Success of Business Failure Prediction Models - An International Survey. Journal of Banking and Finance, 8(2), 171-198.

Amburgey, T.L. and Hayagreeva, R. (1996). Organizational Ecology: Past, Present, and Future Directions. Academy of Management Journal, 39(5), 1265-1286.

Amburgey, T.L., Kelly, D. and Barnett, W.P. (1993). Resetting the clock: the dynamics of organizational change and failure. Administrative Science Quarterly, 38, 51-73.

Anderson, P. and Tushman, M. (2001). Organizational Environments and Industry Exit: The Effects of Uncertainty, Munificence and Complexity. Industrial and Corporate Change, 10, 675-711

Argenti, J. (1976). Corporate collapse: The causes and symptoms. New York. JohnWiley.

Aziz, A., Emanuel, D. C., and Lawson, G. H. (1988). Bankruptcy Prediction - An Investigation of Cash Flow Based Models. Journal of Management Studies, 25(5), 419437.

Bain, J. S. (1956). Barriers to New Competition. Cambridge. MA: Harvard University Press.

Balderston, F.E. (1972). Varieties of Financial Crisis. For Foundation Program for Research in University Administration. University of California, Berkeley. 
Barnett, W. P., Greve, R.H. and Park, Y.D. (1994). An evolutionary model of organizational performance. Strategic Management Journal, 15, 11-28.

Bantel, K.A. and Jackson, S.E. (1989). Top Management and Innovations in Banking: Does the Composition of the Top Team Make a Difference?. Strategic Management Journal, 10, 107-124.

Barmash, I. (1973). Great Business Disasters. Ballantine Books, New York.

Barnett, W.P. and Amburgey, T. L. (1990). Do larger organizations generate stronger competition? in J. V. Singh (ed.) Organizational Evolution: New Directions, pp. 246-248, Newbury Park, CA, Sage.

Barron, David N. West, E. and Hannan, Michael T. (1994). A Time to Grow and a Time to Die: Growth and Mortality of Credit Unions in New York City, 1914-1990. American Journal of Sociology, 100, 196- 241.

Barron, N.B. (2001). Organizational Ecology and Industrial Economics: a Comment on Groski. Industrial and Corporate Change, 10(2), 541548.

Baum , J.A. C. and Oliver, C. (1992). Institutional Embeddedness and the Dynamics of Organizational Populations. American Sociological Review, 57, 4,540-559

Baum , J.A. C. and Singh, J. (1994). Organizational niches and the dynamics of organizational mortality. Administrative Science Quarterly, 36, pp.187-218.

Baum, J. A.C. 1996. “Organizational Ecology.” Handbook for Organization Studies, ed.

Baum, J. A. C. and S. J. Mezias, (1992). Localized competition and organizational failure in the Manhattan hotel industry, 1898-1990. Administrative Science Quarterly, 37, 580-604.

Baum, J.A.C and Oliver, C. (1996). The Institutional Ecology of Organizational Founding. Academy of Management Journal, 39, 1378-1427.

Benson, J. (1975). Inter-organizational networks as a political economy. Administrative Science Quarterly, 20(3), 229-249

Boeker, W. (1997). Strategic change: The influence of managerial characteristics and organizational growth. Academy of Management Journal, 40(1), 152-170.

Burt, S.L; Mellahi, K; Jackson, P; and Sparks, L. (2002). Retail Internationalisation and Retail Failure: issues from the case of Marks and Spencer, The International Review of Retail, Distribution and Consumer Research, 12,191-219. 
Boone, C. and Van -Witteloostuijn, A. (1995). Industrial Organization and Organizational Ecology: The Potentials for Cross-Fertilization, Organization Studies, 16(2): 265-298

Boulding, K.A. (1950). A Reconstruction of Economics. Wiley, New York. Bourgeois, L.J. III. (1984). Strategic management and determinism. Academy of Management Review, 9, 586-598.

Brockner, J. (1992). The escalation of commitment to a failing course of action: Toward theoretical progress. Academy of Management Review, 17, 39-61.

Brown, A.D. and Starkey, K., (2000), Organizational Identity and Organizational Learning: A Psychodynamic Perspective. Academy of Management Review, 25 (1), 102120.

Brown, M. (1982). Administrative succession and organizational performance: The succession effect. Administrative Science Quarterly, 27, 1-16.

Bruderl, J. and Schussler, R. (1990). Organizational Mortality: the liabilities of newness and adolescence. Administrative Science Quarterly, 36, 187-218.

Bruno, Albert V. and Joel K. Leidecker. (1998). Causes of New Venture Failure: 1960's vs. 1980's. Business Horizons, 31, 51-57

Brush, T.H., Bromiley, P., and Hendrickx, M. (1999). The Relative Influence of Industry and Corporation on Business Segment Performance: An Alternative Estimate. Strategic Management Journal, 20, 519-547

Cameron, K.A, Sutton, R.I and Whetten, A.D. (1988). Readings in Organizational Decline: Framworks, Research, and Prescriptions. Ballinger, Cambridge, Massachusetts.

Cameron, K.S. (1983). Strategic Responses to Conditions of Decline: Higher Education and the Private Sector, Journal of Higher Education, 54, 359-380.

Carroll , G.R. and Swaminathan, A. (2000). Why the Microbrewery Movement? Organizational Dynamics of Resource Partitioning in the American Brewing Industry after Prohibition. American Journal of Sociology, 106, 715-762.

Carroll, G. and Delacroix, J. (1982). Organizational mortality in the newspaper industries of Argentina and Ireland: an ecological approach. Administrative Science Quarterly, 27,169-198.

Carroll, G. R. (1983). A stochastic model of organizational mortality: Review and reanalysis. Social Science Research, 46, 585-599.

Carroll, G. R. (1984). Dynamics of publisher succession in newspaper organizations. Administrative Science Quarterly, 29, 303- 329. 
Dambolena, I. G. (1983). The Prediction of Corporate Failures. OMEGA-International Journal of Management Science, 11(4), 355-364.

D'Aveni, R.A and IC MacMillan (1990). Crisis and Content of Managerial Communications:A Study of the Focus of Attention of Top Managers in Surviving and Failing Firms. Administrative Science Quarterly, 35, 634-657.

D'Aveni, RA (1989). The aftermath of organizational decline: A longitudinal study of the strategic and managerial characteristics of declining firms. Academy of Management Journal, 32, 577-605.

Delacroix, J., Swaminathan, A. and Solt, E.M. (1989). Density dependence versus population dynamics: An ecological study of failings in the California wine industry. American Sociological Review, 54, 245-262.

Dess, G. G. and Beard, D.W. (1984). Dimensions of Organizational Task Environments, Administrative Science Quarterly, 29, 52-73.

Dimitras, A. I., Zanakis, S. H., and Zopounidis, C. (1996). A Survey of Business Failures with an Emphasis on Prediction Methods and Industrial Applications. European Journal of Operational Research, 90(3), 487-513.

Dobrev, D.S., Kim, Tai-Young, and Hannan, M.T. (2001). Dynamics of Niche Width and Resource Partitioning. American Journal of Sociology, 106(5), 1299- 1337.

Duchesneau, D. A. and W. B. Gartner (1990). A Profile of New Venture Success and F ailure in an Emerging Industry, Journal of Business Venturing , 5, 297- 312,

Eisenhardt, K.M. (1989). Making Fast Strategic Decisions in High-Velocity Environments. Academy of Management Journal, 32(3), 543-576.

Fichman, M. and Levinthal, D.A. (1991). Honeymoons and the Liability of Adolescence: A New Perspective on Duration Dependence in Social and Organizational Relationships. Academy of Management Review, 16 (2), 442-468.

Fink, S. (1986). Crisis Management: Planning for the Inevitable. AMACOM.

Flamholtz, C.E and Aksehirli, Z. (2000). Organizational Success and failure: An Empirical Test of a Holistic Model. European Management Journal, 18(5), 488-498.

Frank, M. Z., (1988). An Intertemporal Model of Industrial Exit. Quarterly Journal of Economics, 103, 333-344.

Freeman, John H., G. R. Carroll, and M. T. Hannan (1983). The liability of newness: Age dependence in organizational death rates. American Sociological Review, 48, 692- 
710.

Gaskill, L.R., Van Auken, H.E., and Manning, R.A. (1993). A Factor Analytic Study of the Perceived Causes of Small Business Failure. Journal of Small Business Management, 31(4), 18-31

Gemawat, P. and Nalebuff, B. (1985). Exit. RAND Journal of Economics, 16, 184-194.

Geroski, P.A. (2001). Exploring the Niche Overlaps Between Organizational Ecology and Industrial Economics, Industrial and Corporate Change, 10, 507-540.

Ghemawat, P. (1991). Commitment: the dynamic of strategy. Free Press: New York.

Goltz, S.M. (1992). A sequential learning analysis of decisions in organizations to escalate investments despite continuing cost or losses. Journal of Applied Behaviour Analysis, 25, 561-574.

Greenhalgh, L., Lawrence, A.T., and Sutton, R.I. (1988). Determinants of workforce reduction strategies in declining organizations. Academy of Management Review, 13, 241-254.

Greening, D.W. and Johnson, R.A. (1996). Do Managers and Strategies Matter? A Study in Crisis. Journal of Management Studies, 36, 25-51.

Greenwood, R. and Hining, C. R. (1996). Understanding Radical Organizational Change: Bringing Together the Old and the New Institutionalism. Academy of Management Review, 21(4), 1022- 1054.

Greve, H. (1999). The Effect of Core Change on Performance: Inertia and Regression Toward the Mean. Administrative Science Quarterly, 44(3): 590-614.

Grusky, O. (1963). Managerial succession and organizational effectiveness. American Journal of Sociology, 69, 21-31.

Guest, Robert H. (1962). Managerial succession in complex organizations. American Journal of Sociology, 68, 47-55.

Hambrick, D. and Mason, P. (1984). Upper echelons: the organization as a reflection of top managers. Academy of Management Review, 9, 193-206.

Hambrick, D. C. and D'Aveni, R. A. (1988). Large Corporate failures as downward spirals. Administrative Science Quarterly, 33, 1-23.

Hambrick, D.C. and Fukutomi, G. (1991). "The Seasons of a CEO's Tenure". Academy of Management Review, 16,4, 719-742 
Hambrick, D.C., Cho, T.S. and Chen, M-J. (1996). The Influence of Top Management Team Heterogeneity on Firms' Competitive Moves. Administrative Science Quarterly, 41, 659-684.

Hannan, M.T. (1986). Uncertainty, Diversity and Organizational Change. In Neil J. Smelser and Dean, R. Gerstein, (eds.). Social and Behavioral Sciences: Discoveries over fifty years. Washington, D.C. : National Academy Press.

Hannan, M.T. (1997). Inertia, Density and Structure of Organization Populations: Entries in European Automobile Industries, 1886-1981. Organization Studies, 18, 193-228.

Hannan, M. T. and Carroll, G.R. (1992). Dynamics of Organizational Populations. Density, Legitimation, and Competition, Oxford, Oxford University Press.

Hannan, M. T. and J. Freeman, (1978) The Population Ecology of Organizations, in M.W. Meyer and Associates (Eds.) Environments and Organizations: Theoritical and Empirical Perspectives. San Francisco: Jossey-Bass.

Hannan, M. T., Carroll, R.G. Dobrev, S.D. and Joon, Han. (1998). Organizational Mortality in European and American Automobile Industries, Part I: Revisiting the Effects of Age and Size. European Sociological Review, 14, 279-302.

Hannan, M.T. and Freeman, J.H. (1988). The ecology of organizational mortality: American labor unions, 1836-1985. American Journal of Sociology, 94, 25-52.

Hannan, M.T. and Freeman, J.H. (1977). The population ecology of organizations. American Journal of Sociology, 83, 929-984.

Hannan, M.T. and Freeman, J.H. (1984). Structural inertia and organizational change. American Sociological Review, 49, 149-164.

Hannan, M.T., and Freeman, J. (1989). Organizational Ecology. Cambridge: Harvard University Press

Hannan, M.T., Barron, D. and Carroll, G.R. (1991). On the interpretation of dependence in rates of organizational mortality: A reply to Peterson and Koput. American Sociological Review, 56, 410-415.

Harrigan, K. R. ( 1982). Exit Decisions in Mature Industries. Academy of Management Journal, 25(4), 707-732.

Haveman, H. A. (1992). Between a Rock and a hard place: Organizational change and performance under conditions of fundamental environmental transformation. Administrative Science Quarterly 32 , 48-75 
Haveman, H. A., and Mukti V. Khaire. (2003). Survival beyond succession? The contingent impact of founder succession on organizational failure. Journal of Business Venturing, Forthcoming.

Hawley, A. (1950). Human Ecology: a theory of community structure, Ronald Press, NY

Heather A. (1993). Ghosts of managers past: Managerial succession and organizational mortality. Academy of Management Journal, 36, 864-881.

Helmich, Donald L. (1974). Organizational growth and succession patterns. Academy ofManagement Journal, 17, 771-775.

Henderson, A. D. (1999). Firm strategy and age dependence: A contingent view of the liability of newness, adolescence, and obsolescence. Administrative Science Quarterly, 44(2), 281-314.

Hodgkinson, P.G and Wright, G. (2003). Confronting Strategic Inertia in a Top Management Team: Learning From Failure. Organization Studies, 24 (Forthcoming)

Holsti, O.R. (1978). Limitations of Cognitive Abilities in the Face of Crisis. in CF Smart, WT Stanbury (eds) Studies in Crisis Management. Toronto, Butterworth.

Huff, A. and Schwenk, C. R. 1990. Bias and sense making in good times and bad. In A. Huff (ed.), Mapping Strategic Thought. New York: Wiley, 1990, pp.98-108.

Ingram,P. L. (1993).Old, Tired and Ready to Die: The Age Dependence of Organizational Mortality Reconsidered. Paper presented at the Academy of Management National Meetings, Atlanta, GA

Jackson, P., Mellahi, K. and Sparks, L. (2005). Shutting Up Shop: Understanding the International Exit Process in Retailing, Service Industries Journal, 25, Forthcoming

Janis, I.L. (1972). Victims of groupthink. Boston: Houghton-Mifflin

Janis, I.L. (1982). Victims of groupthink ( $2^{\text {nd }}$ edition). Boston: Houghton-Mifflin.

Johnson, C. G. (1970). Ratio analysis and the prediction of firm failure. The Journal of Finance, 5, 1166-1168

Jovanovic, B. and Lach S. (1989). Entry, Exit and Diffusion with Learning by Doing, American Economic Review, 79, 690-699.

Katz, R. (1982). The effects of group longevity on project communication and performance. Administrative Science Quarterly, 27, 81-104. 
Keisler, S. and Sproull, L. (1982). Managerial Response to Changing Environment: Perspectives on Problem Sensing from Social Cognition. Administrative Science Quarterly, 27, 548-570.

Keisler, S., and Sproull, L., (1982). Managerial Response to Changing Environment: Perspectives on Problem Sensing from Social Cognition. Administrative Science Quarterly, 27: 548-570.

Kelly, D. and Amburgey, T.L. (1991). Organizational inertia and momentum: a dynamic model of strategic change. Academy of Management Journal, 34, 591-612.

Klepper, S. (1997). Industry Life Cycle, Industrial and Corporate Change, 6, 145-179.

Kroll, M., L. Toombs, and P. Wright, (2000). Napoleon's Tragic March Home from Moscow: Lessons in Hubris for Contemporary Executives. Academy of Management Executive, 14, 117-128

Larson, C.M. and Clute, C.R. (1979). The Failure Syndrome. American Journal of Small Business, 4(2), 35-43

Laughlin, H. P. (1970). The ego and its defenses. New York: Appleton-Century-Crofts.

Lawrence, P. R., and Lorsch. J. W. (1967). Organization and Environment. Boston: Harvard Business School Press.

Levinthal, D. and M. Fichman. (1988). Dynamics of Interorganizational Attachments: Auditor Client Relationships. Administrative Science Quarterly, 33: 345-369.

Levinthal, Daniel A. (1991). Random walks and organizational mortality. Administrative Science Quarterly, 36, 397-420.

Lippman, S. A. and Rumelt, R.P. (1982). Uncertain Imitability: An Analysis of Inter firm Differences in Efficiency under Competition. The Bell Journal of Economics, 13: 418438.

Macoby, M. (2000). Narcissistic leaders: The incredible pros, the inevitable cons. Harvard Business Review, January -February, 68-78

Manz, C.C. and Sims, H.P. Jr,. (1982). The potential of "groupthink" in autonomous groups. Human Relations, 35, 773-784.

March, J. G. (1995). The future, disposable organizations and the rigidities of imagination. Organization, 2, 427-440.

Mauri, A.J. and Michaels, M.P. (1998), Firm and Industry Effects within Strategic Management: An Empirical Examination. Strategic Management Journal, 19, 211-219 
McCain, B.E. (1986). Continuing investment under conditions of failure: A laboratory study of the limits of escalation. Journal of Applied Psychology, 71, 280-284.

McGahan, A.M., and Porter, M.E. (1997). How much does Industry Matter, Really?. Strategic Management Journal, 18, 15-30

Mcgurr, P. T., and Devaney, S. A. (1998). Predicting Business Failure of Retail Firms An Analysis Using Mixed Industry Models. Journal of Business Research, 43(3), 169176.

McKinley, W., Zhao, J., and Rust, K.G. (2000). A Sociocognitive Interpretation of Organizational Downsizing. Academy of Management Review, 25, 227-243

Mellahi, K and Jackson, P. (2002). Responding to a Crisis in a Successful Organization: The Impact of Top Management Characteristics” BAM 2002 , British Academy of Management Conference, Middlesex University, September 2002

Mellahi, K; Jackson, P; and Sparks, L. (2002). An Exploratory Study into Failure in Successful Organizations: The Case of Marks and Spencer. British Journal of Management, 13(1), 15-30

Meyer, J. W.and B Rowan, B. (1977). Institutionalized organizations: Formal structure as myth and ceremony. American Journal of Sociology, 83, 340-363.

Michel, J. G. and Hambrick, D. C. (1992). Diversification posture and top management team characteristics. Academy of Management Journal, 35,1, 9-37.

Miller, D. (1990). The Icarus Paradox: How Exceptional Companies Bring About Their Own Downfall: New Lessons in the Dynamics of Corporate Success, Decline, and Renewal. New York, NY: Harper Business.

Miller, D. (1991). Stale in the saddle: CEO tenure and the match between organization and environment. Management Science, 37, 34-52

Miller, D. (1992). Environmental fit versus internal fit. Organization Science, 3, 159-178.

Miller, D. (1993). The architecture of simplicity. Academy of Management Review, 18(1), 116-138.

Miller, D. and Friesen, P. (1984). Organizations: A quantum view. Englewood Cliffs, NJ: PrenticeHall.

Miller, D.T. and Ross, M. 1975). Self-serving biases in the attribution of causality: fact or fiction. Psychology Bulletin, 82, 213-225. 
Miner, S.A, Kim, Ji-Yub, and Haunschild, P. (1999). Fruits of failure: organizational failure and population-level learning. Advances in Strategic Management, 16, 187-220

Mone, M.A., McKinley, W. and Barker, V. L. (1998). Organizational decline and innovation: A contingency framework. Academy of Management Review, 23, 115-132.

Nelson, R., Winter, S. (1982). An Evolutionary Theory of Economic Change. Harvard University Press, Cambridge

Nelson, R.R. (1995). Recent Evolutionary Theorizing and Economic Change. Journal of Economic Literature, 33, 48-49.

Ocasio, W. (1993). The structuring of organizational attention and the enactment of economic adversity: A reconciliation of theories of failure-induced change and threatrigidity. Working paper, Sloan School of Management, Massachusetts Institute of Technology, Cambridge, MA.

O'Neill, H. and Duker, J. (1986). Survival and Failure in Small Business. Journal of Small Business Management, 24(1), 30-37.

Peterson, S.R., Owens, D.P., Tetlock, E.P., Fan, T.E and Martorana, P. (1998). Group Dynamics in Top Management Teams: Groupthink, Vigilance, and Alternative Models of Organizational Failure and Success. Organizational Behavior and Human Decision Processes, 73 (2/3), 272-305.

Peterson, T. and Koput, K.W. (1991). Density dependence in organizational mortality: Legitimacy of unobserved heterogeneity. American Sociological Review, 56, 399-409.

Pfeffer, J. (1992). Managing With Power: Power and Influence in Organizations. Boston MA: Harvard Business School Press.

Pfeffer, J. and Salancik, G. R. (1978). The External Control of Organizations. New York: Harper and Row.

Pitcher, P. and Smith. A. (2001). Top Management Team Heterogeneity: Personality, Power, and Proxies. Organization Science, 12,1, 1-18.

Ranft, L. A. and O'Neill, M, H. (2001). Board Composition and High-flying Founders: Hints of trouble to come?. The Academy of Management Executive, 15, 126-138.

Rosenbloom, R.S. and Christensen, C.M. (1994). Technological Discontinuities, Organizational Capabilities and Strategic Commitments. Industrial and Corporate Change, 3, 655-685.

Ross, J and Staw, B.M. (1993). Organizational escalation and exit: lessons from the Shoreham nuclear power plant. Academy of Management Journal, 36, 701-732. 
Rumelt, R.P. (1991). How Much Does Industry Matter? Strategic Management Journal, 12(3), 167-185.

Schumpeter, J. (1942). Capitalism, Socialism and Democracy. Harper and Brothers: New York.

Schulman, P.R. (1989). The "logic" of organizational irrationality. Administration and Society, 21, 31-33.

Scott, R. 1998. Organizations: Rational, natural and open systems, 4th ed., New York: Prentice Hall.

Scott, W.R. (1992). Organizations: Rational, Natural and Open Systems. Prentice Hall: Englewood Cliffs, NJ.

Sheppard, J. P. (1995). A Resource Dependence Approach to Organizational Failure. Social Science Research, 24(1), 28-62.

Sheppard, P.J. (1994). Strategy and Bankruptcy: An exploration into organizational death. Journal of Management, 20, 795-833.

Singh, J. V. and Lumsden, C.J. (1990). Theory and Research in Organizational Ecology. Annual Review of Sociology, 16,161-95

Singh, J., House, R. and Trucker, D. (1986). Organizational change and organizational mortality. Administrative Science Quarterly, 31, 587-611.

Slater, S and Narver, J. (1994). Does competitive environment moderate the market orientation performance relationship. Journal of Marketing, 58, pp. 46-55

Smart, C. and Vertinsky I. 1984. Strategy and the Environment: A Study of Corporate Responses to Crises. Strategic Management Journal, 8(3): 199-214.

Starbuck, W.H., Greve, A., and Hedberg, B.L.T. (1978). Responding to Crisis. Journal of Business Administration, 9, pp.111-137.

Starbuck, William H. and Mezias, Jorn, M. (1996).Opening Pandora's box:

Studying the accuracy of managers' perceptions. Journal of Organizational Behavior, 17(2): 99-117.

Staw, B., Sandelands, L. and Dutton, J. E. (1981). Threat-rigidity cycles in organizational behavior: A multi-level analysis. Administrative Science Quarterly, 26, 501-524 
Staw, B.M. (1976). Knee-deep in the big muddy: A study of escalating commitment to a course of action. Organizational Behaviour and Human Performance, 16, 27-44.

Stinchcombe, A.L. (1965). Social structures and organizations. J. G. March (ed.) Handbook of Organizations, pp. 142-193. Chicago: Rand McNally.

Stoeberl, P.A, Parker, G.E., and Joo, Seong-Jong (1998). Relationship Between Organizational Change and Failure in the Wine Industry: An Event History Analysis. Journal of Management Studies, 35(4), 537-555.

Sull, D.N., Tedlow, R.S. and Rosenbloom, R.S. (1997). Managerial Commitments and Technological Change in the US Tire Industry. Industrial and Competitive Change, $\mathbf{6}$, 461-501.

Sutton, J. (1997).Gilbrat's Legacy. Economic Literature, 35 (1), 40-59

Swaminathan, A. (1996). Environmental Conditions at Founding and Organizational Mortality: A Trial-by-Fire Model. Academy of Management Journal, 39, 1350-1377.

Szilagyi, A. D. and Schweiger, D. M. (1984). Matching managers to strategies: A review and suggested framework. Academy of Management Review, 9(4), 626- 637.

Turner, M. E., and Pratkanis, A. R. (1998). A social identity model of groupthink.

Organizational Behavior and Human Decision Processes, 73, 210-235.

Tushman, M and Anderson, P. (1986). Technological Discontinuities and Organizational Environments. Administrative Science Quarterly, 31, 439-465.

Ulrich, D. (1987). The Population Perspective: Review, Critique, and Relevance, Human Relations, 40, 137-152.

Van de Van, A.H. (1989). Nothing is quite so practical as a good theory. Academy of Management Review, 14(4), 486-489.

Virany, B., Tushman, M.L. and Romanelli, E. (1992). Executive succession and organization outcomes in turbulent environments: An organizational learning approach. Organization Science, 3 (1), 72-91

Wagner, J. A. III and Gooding, R. Z. 1997. Equivocal information and attribution: An investigation of patterns of managerial sensemaking. Strategic Management Journal, 18(4): 275-286.

Wanous, J. (1980). Organizational entry: Recruitment, selection and socialization of Newcomers. Reading, MA: Addison-Wesley. 
Weitzel, W., andJohnson, E. (1989). Decline in organizations: A literature integration and extension. Administrative Science Quarterly, 34, 91-109

Whetten, D.A. (1980). “Organizational decline: Sources, responses and effects.” Pp 342374 in J. Kimberly and R. Miles (eds.) Organizational Life Cycles. San Francisco: Jossey-Bass.

Whetten, D.A. (1988). Organizational growth and decline processes, in readings. Pp. 3-19 in K. S. Cameron, R. I. Sutton and D. A. Whetten (Eds.), Organizational Decline, Frameworks, Research, and Prescriptions. Cambridge, MA: Ballinger.

Wholey, Douglas R., J. B. Christianson, and S. M. Sanchez 1992. Organization size and failure among health maintenance organizations. American Sociological Review, 57, 829842.

Wiersema M. and Bantel. K. (1992). Top Management Team Demography and Corporate Strategic Change. Academy of Management Journal, 35, 91-121.

Wilcox, J. W. (1971). A simple theory of financial ratios as predictors of failure. Journal of Accounting Research, 2, 389-395.

Witteloostuijn, van, A. (1998). Bridging Behavioral and Economic Theories of Decline: Organizational Inertia, Strategic Competition, and Chronic Failure. Management Science, 44, 501-519. 
Figure 1 Industry Life Cycle

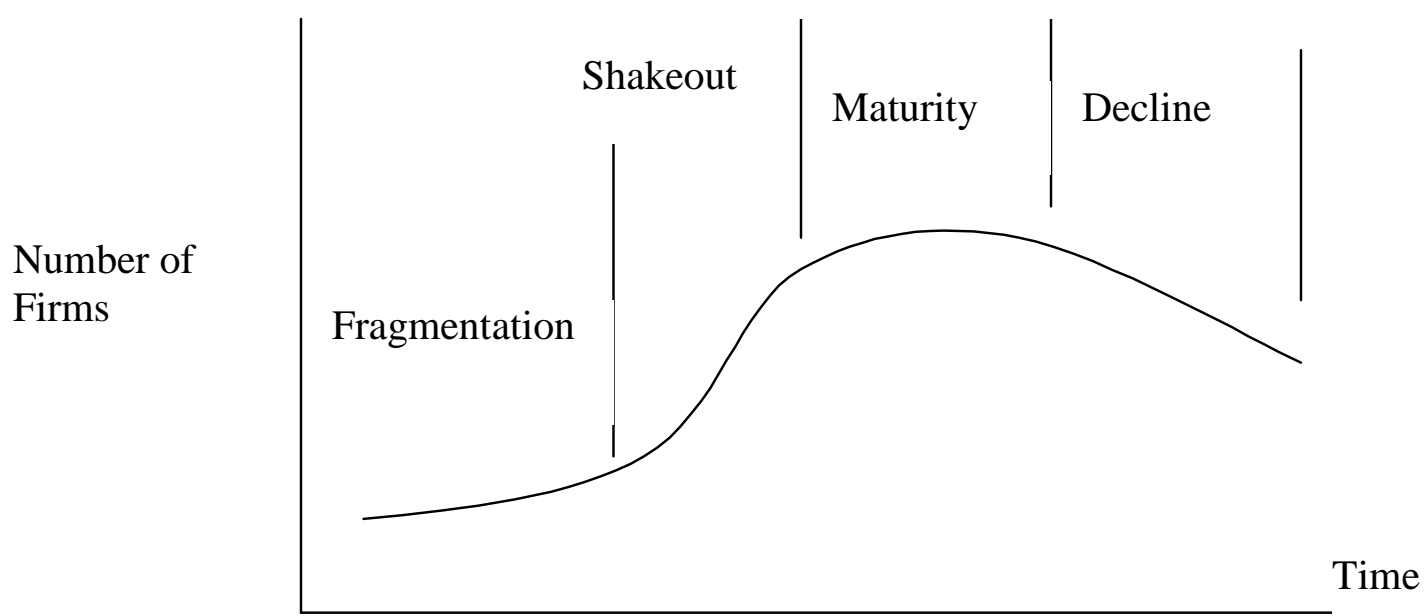


Figure 2. An Integrative Framework of Determinants of Organizational Failure

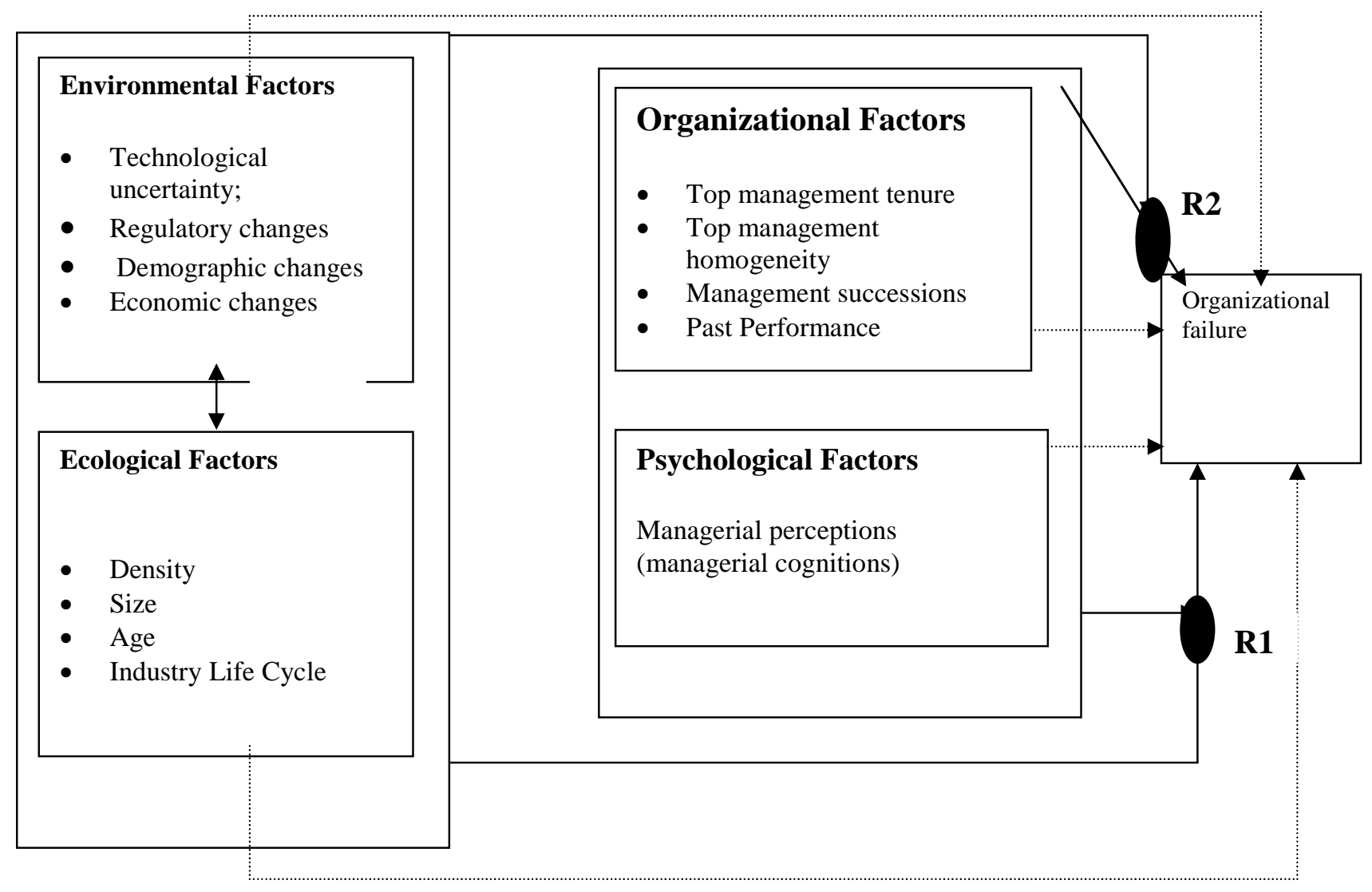




\section{Endnotes}

' For instance Geroski (2001) notes that while organizational ecologists focus on organizational forms, 10 scholars believe that what organizations do matters more than their forms.

ii It is worth pointing out that a small body of research argues that older organizations may fail because of their inability to respond to external pressures, in part because they are attentive to the expectations of established stakeholders. This is referred to as a "rigidity of aging" (c.f. Singh and Lumsden, 1990). In contrast, the "fluidity of aging" thesis posits that as organizations age they are in fact more likely to experiment with change, since investment in organizational maintenance calls for an ability to adapt to changing environmental circumstance.

iii For a broad review of the evolution of the theory of groupthink and its body of empirical evidence, see Turner and Pratkanis, (1998).

iv Research shows that people tend to overestimate their own influence on successes while they blame failure on external uncontrollable factors. (c.f. Wagner and Gooding, 1997; Huff and Schwenk, 1990). For a review of management misperceptions see Starbuck and Mezias (1996).

${ }^{\vee}$ A fragmentation trap emerges when too many new middle range theories are proposed at a too fast pace in order for the scientific community to be able to evaluate each contribution properly and to integrate them into a reasonable coherent knowledge structure.

vi Van de Van (1989) argues that the tensions, inconsistencies, and contradictions between theories offer substantial opportunities to improve our understanding of organizational phenomena and to enhance theory development.

vii OE scholars rely on long time series and follow, year after year, every single event at every single firm in the population from its initial phase. 